\title{
KONSTRUKSI PERMAINAN TALI LUEK SEBAGAI TEKNIK EMPOWERING KONSELING MODEL KIPAS
}

\author{
Nisa Ariantini, Suriata \\ Fakultas Keguruan dan Ilmu Pendidikan_Universitas Borneo Tarakan \\ Email: ariantiny.nisa@gmail.com
}

\begin{abstract}
Permainan tradisional menanamkan nilai-nilai budaya dan norma social dalam perkembangan peserta didik di sekolah. Di Kalimantan Utara terdapat banyak jenis permainan tradisioal, seperti permainan Tali Luek yang. Tujuan penelitian ini, mendeskripsikan unsur-unsur permainan Tali Luekyang dapat digunakan sebagai teknik pelayanan bimbingan dan konseling dalam Konseling Model KIPAS.

Penelitian ini menggunakan penelitian kualitatif dengan metode interaksionisme simbolik, yang dilaksanakan di SMP Negeri 3 Krayan. Hasil penelitian ini menunjukkan konstruksi dari setiap permainan yang diantaranya alat-alat yang digunakan, aturan dalam permainan, dan cara bermain, serta penggunaan permainan pan fabat dan gumbak karit sinan sebagai strategi empowering dalam Konseling Model KIPAS.
\end{abstract}

Kata kunci : permainan tali luek, teknik empowering, konseling model KIPAS

\section{PENDAHULUAN}

Kemajuan teknologi yang semakin pesat ternyata mempengaruhi aktivitas bermain anak. Sekarang, anak-anak lebih sering permainan digital seperti video gamies, playstation, dan games online. Permainan ini disebut permainan modern karena dimainkan menggunakan peralatan canggih dengan teknologi mutakhir. Sementara, permainan tradisional tidak begitu membutuhkan peralatan saat dimainkan, kalaupun ada peralatan yang digunakan hanya menggunakan peralatan yang sederhana yang mudah didapatkan disekitar, seperti batu, kayu, karet, atau sandal.

Permainan tradisional sekarang ini sudah mulai jarang dimainkan, karena anak semakin banyak yang lebih memilih bermain menggunakan gadget daripada berpanas-panas bermainan diluar rumah. Pelestarian permainan tradisional penting untuk dilakukan dengan cara memperkenalkan dan memainkan permainan tradisional bersama anak, disertai dengan upaya penyadaran kepihak-pihak terkait manfaat bermain permainan tradisional ke 
anak dan orang tua. Sekolah bisa menjadi salah satu tempat yang dapat digunakan untuk melestarikan permainan tradisional. Seperti pelaksanaan yang dilakukan guru BK bisa menggunakan permainan tradisional sebagai media layanan di sekolah.

Pemberian teknik permainan yang tepat dapat mengembangkan potensi siswa sesuai dengan kebutuhannya (Anita, Sugiyo, \& Suwarjo, 2013). Salah satu permainan tradisional yang berkembang di Indonesia, tepatnya di wilayah Kalimantan Utara, adalah permainan Tali Luek. Permainan ini pada umumnya dikenal dengan nama Gobak Sodor di beberapa wilayah lain di Indonesia (W. P. Kurniawan \& Zawawi, 2017). Konselor di sekolah pada dasarnya telah melaksanakan upaya-upaya bantuan dalam rangka mengembangkan diri dan pengentasan terhadap permasalahan sosial siswa. Menurut Gibson (2011) bimbingan dan konseling merupakan pelayanan bantuan yang diberikan konselor kepada peserta didik baik secara individu maupun kelompok, agar mandiri dan berkembang secara optimal.

Melalui pemberian metode yang khas dan unik baik dalam pelaksanaan layanan di dalam kelas atau di luar kelas, Guru BK akan terbantu untuk mengembangkan diri dan sosial siswa (Mappiare-AT, 2012). Dengan memberikan pelayanan menggunakan permainan tal luek. Salah satunya guru BK bisa mengadopsi dari Konseling Model KIPAS berbasis kebudayaan dengan menggunakan permainan traditional sebagai teknik dalam pemberian layanan bimbingan atau konseling kelompok. Konseling model KIPAS memberikan alternatif strategi modifikasi dengan menggunakan teknik permainan tradisional.

Fokus dalam tulisan ini adalah mendeskripsikan unsur-unsur permainan Tali Luek yang dapat digunakan sebagai teknik dalam strategi konseling model KIPAS, sehingga dapat digunakan guru BK sebagai metode pelayanan untuk mengembangkan diri siswa. Tulisan ini diharapkan dapat dijadikan referensi oleh mahasiswa; konselor sekolah; dan penelitian lainnya.

\section{METODE PENELITIAN}

Penelitian ini menggunakan metode kualitatif untuk mengungkap gejala secara holistik-kontekstual melalui pengumpulan data dari latar alami dengan memanfaatkan diri peneliti sebagai instrumen kunci. Penelitian ini menggunakan rancangan tipe interaksionisme simbolik, yaitu peneliti memaknai interaksi antar inidividu dan simbolsimbol yang nampak seperti; bahasa; ritme-ucap; penekanan kata; postur; gestur; mimik dari interaksi yang terjadi dipermainan serta makna yang individu berikan terhadap itu semua.

Penelitian ini menggunakan teknik pengambilan sampel secara 
purposive. Subjek dalam penelitian ini adalah siswa-siswa kelas VII, dan VIII dari SMP Negeri 3 Krayan sebanyak 8 orang. Terpilihnya subjek penelitian didasarkan kriteria, antara lain: 1) subjek pernah memainkan permainan tangkap lokam sebelumnya, 2) subjek dapat diajak bekerjasamaa untuk melakukan permainan, 3) subjek dapat dijadikan informan dalam penelitian, serta 4) subjek dapat menjalin hubungan akrab dengan peneliti.

Kehadiran dan keterlibatan peneliti di lapangan adalah untuk menemukan makna dan tafsiran dari subjek yang tidak bisa digantikan dengan alat lain (non human) dalam hal ini peneliti memanfaatkan dirinya sebagai instrumen utama. Adapun teknik analisis data dalam penelitian ini menggunakan beberapa strategi, diantaranya describing data, dan categorization data.

\section{HASIL DAN PEMBAHASAN}

Terdapat beberapa unsuru-unsur dalam permainan Tali Luek, diantaranya:

a. Alat Permainan

Permainan ini biasanya bisa dimainkan diberbagai tempat, jika dimainkan dilapangan berpasir maka dibutuhan kayu untuk menggambar garis, kalau bermainnya di lapangan berumput biasanya diperlukan kapur untuk menaburnya menjadi garis atau jika bermainnya dilapangan bersemen maka diperlukan pilox atau kayu arang untuk menggambar garisnya. b. Aturan dalam Permainan

Permianan ini biasanya dimainkan oleh 4-10 orang yang dibagi menjadi dua kelompok berbeda. Setiap kelompok memilih salah satu anggotanya untuk menjadi pemimpin kelompoknya. Ketua kelompok melakukan suit (gajah, orang, semut) untuk menentukan kelompoksiapa yang pertama bermain. Kelompok yang kalah harus menjaga disetiap sisi garis agar tidak dilewati oleh kelompok bermain, kelompok bermain tidak boleh bermain diluar kotak sesuai yang sudah digambar oleh pemain. Pemain yang melewati garis yang seharusnya, maka dianggap kalah.

\section{c. Cara Bermain}

Beberapa pemain menyiapkan area permainan, berbentuk gambar persegi panjang yang didalamnya berisi kotak-kotak. Biasanya jumlah kotak dibuatkan menyesuaikan dengan jumlah pemain yang bermain. Jika masing-masing kelompok terdiri dari 4 orang, maka dibentuklah dengan jumlah 4 kotak. Dimana 1 orang menjaga garis depan, 1 orang dibagian tengah, 1 orang digaris belakang, dan 1 orang lagi menjaga digaris lurus panjang bagian tengah gambar. Kelompok yang bermain bersama-sama untuk masuk kedalam kotak pertama, kelompok bermain berusaha megecoh pemain lawan agar tidak focus menjaga setiap kotak agar kelompok bermain bisa lolos ketahapan kotak selanjutnya. Jika ada salah satu anggota kelompok 
bermain yang berhasil melewati penjaga terakhir, maka anggota tersebut harus kembali lagi masuk dan berusaha keluar dari kotak dipintu awal masuknya tadi. Serta itulah tanda kemenangan bagi setiap kelompok bermain.

Dalam proses langkah Konseling Model KIPAS, guru BK perlu mendeskripsikan beberapa siswa yang memiliki permasalahan atau "urusan inti" untuk dapat mengetahui label "asset terabaikan" atau "asset sebab-sebab" dengan diberikan strategi modifikasi, untuk mengganti menjadi "asset terbarukan" atau "tujuan konseling".

Strategi modifikasi yang cocok untuk teknik permainan Pan Fabat dan Gumbak Karit Sinan, yaitu empowering. Dimana "asset terabaikan" masih banyak siswa yang memiliki power hanya didalam dirinya saja, atau terkadang power yang dikeluarkan sia-sia. Melalui empowering menggunakan teknik permainan Pan Fabat dan Gumbak Karit Sinan, siswa akan mampu menjadi "asset terbarukan" yang berkembang penuh daya dan semangat untuk keluar dari situasi bermasalah. Model konseling KIPAS mengorientasikan bersifat "happy electism" dalam pelaksanaannya di sekolah. Model KIPAS merencanakan tindakan konseling dalam beberapa strategi modifikasi, salah satunya adalah pemberdayaan (empowering) dengan menggunakan permainan tali luek.
Permainan tai luek dapat digunakan oleh guru BK sebagai salah satu teknik bimbingan konseling dalam pelaksanaan layanan konseling. Rusmana (2009) menjelaskan bahwa teknik permainan dalam pelayanan bimbingan dan konseling sebagai sebuah wahana dalam pemecahan masalah melalui peragaan, dengan langkah-langkah identifikasi masalah, analisis dan hasil diskusi. Dimana melalui permainan mampu menumbuhkan empati dan memudahkan dalam penyesuian diri dengan kondisi yang ada karena fungsi dari permainan adalah mengeluarkan masalah dalam diri seseorang.

Gibson (2011) mengungkapkan bahwa pelaksanaan konseling dapat membantu seseorang memahami dirinya, mencegah masalah, mampu memperbaiki diri, serta menjalankan perkembangan secara optimal melalui informasi serta pengalaman lewat aktivitas kelompok. Dalam hal ini, permainan tali luek dapat digunakan sebagai salah satu teknik sebagai strategi konseling model KIPAS untuk meningkatkan perkembangan bidang bimbingan dan konseling siswa.

\section{KESIMPULAN}

Permainan Tali Luek memiliki unsur-unsur diantaranya alat yang digunakan, aturan-aturan dalam permainan, serta cara memainkan permainan tersebut. Permainan tali luek dapat digunakan guru BK 
sebagai salah satu teknik pelayanan di sekolah, karena melalui pemberian teknik layanan yang khas, dan unik baik dalam pelaksanaan konseling didalam ataupun diluar kelas, akan membantu guru BK dalam mengembangkan diri siswa.

\section{REFERENSI}

Rusmana, N. 2009. Bimbingan dan Konseling kelompok di Sekolah (Metode, Teknik, dan Aplikasi). Bandung: Rizqi Press.

Gibson, Rl \& Mitchell. 2011. Bimbingan dan Konseling. Yogyakarta: Pustaka Pelajar.

Astuti, Anita Dewi. 2013. Model Layanan BK Kelompok Teknik Permainan (Games) Untuk Meningkatkan Keterampilan Komunikasi Interpersonal Siswa. Jurnal Bimbingan Konseling 2(1).

W. P. Kurniawan, MA Zawawi. 2017. Pengenalan Permainan Tradisional GOTENG (Gobak Sodor dan Bentengan) untuk Membangun Karakter Siswa Sekolah Dasar Kelas Atas. Jurnal SPORTIF: Jurnal Penelitian Pembelajaran 3 (2). 